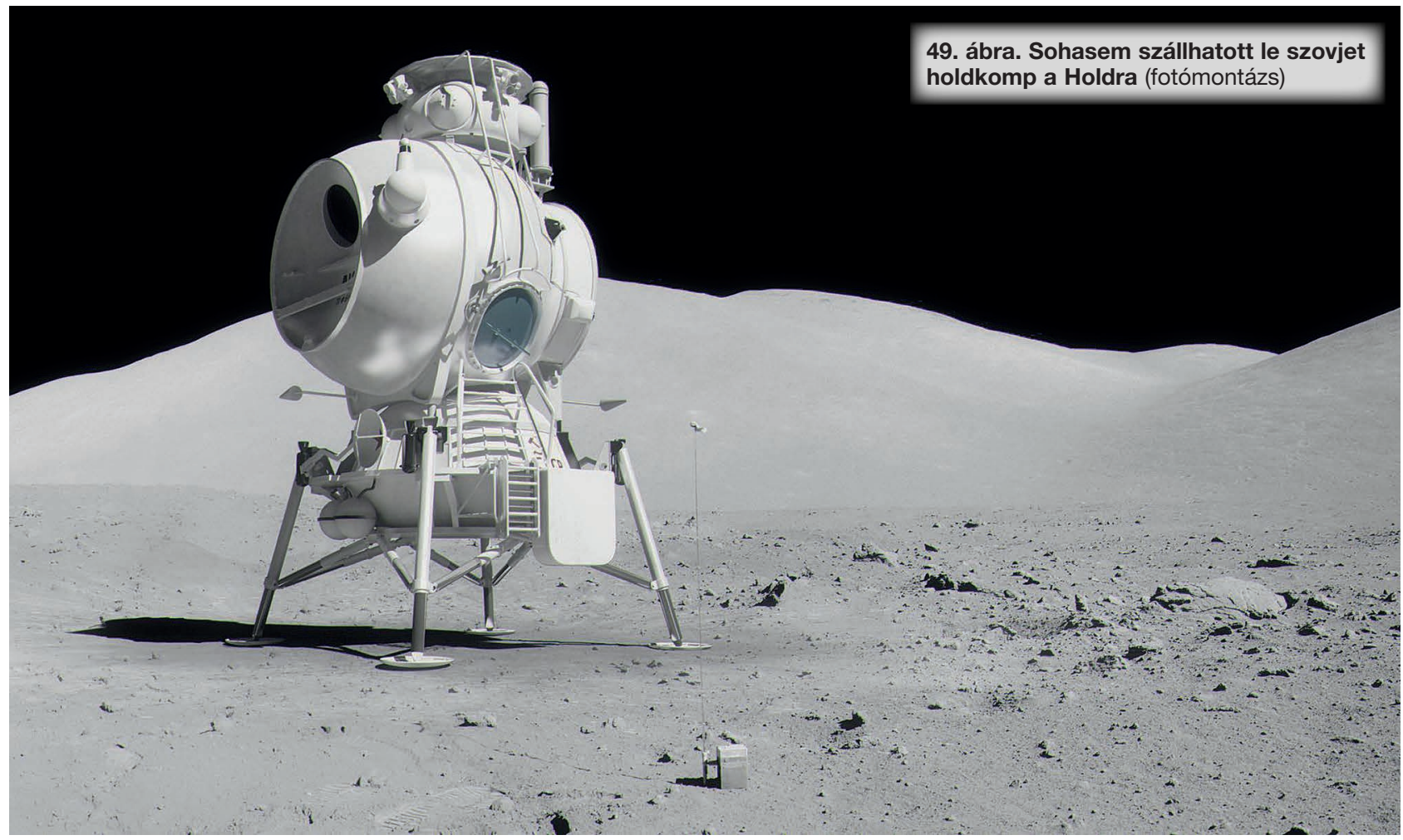

\title{
Schuminszky Nándor*
}

\section{Verseny a Holdért - 50 év után v.reszz Miért veszített a Szovjetunió?}

\begin{abstract}
964 októberében a szovjetek elérkeztek a második kritikus ponthoz. Új politikai vezetés került hatalomra, és rövidesen megkezdődtek a belső villongások, harcok a pártvezetés új tagjai között, háttérbe szorítva az ürkutatási program kérdéseit. Az 1964 augusztusában megfogalmazott N1-L3 program fokozatosan vesztette el jelentőségét, nagyjából még két évig vegetált. Ugyanekkor élt még az UR-500/L1 program, vagyis a Hold megkerülésének terve, készültek a nagyszabású Voszhod ürrepülésekre, és egy pillanatra sem mondtak le a kozmoszban szőtt katonai tervekről sem.
\end{abstract}

\section{Az AKARAT VÁLSÁGA}

A szovjetek 1965 elején előzték meg utoljára az amerikaiakat, amikor Alekszej Leonov végrehajtotta a világ első ürsétáját. Augusztusban Leonyid Szmirnovnak, a Szovjetunió Minisztertanácsa VB titkárának vezetésével „Az űrhajózás közeli teendői” címmel tartottak értekezletet, amelyen megtárgyalták a tényleges helyzetet. Többek között megállapították, hogy megkezdődött a Szovjetunió lemaradása az Egyesült Államok mögött.
Tovább súlyosította a helyzetet, hogy 1966 januárjában Szergej Koroljov mérnök, rakétatervezó - egy rutinmütétet követően - váratlanul elhunyt. A hatalomváltás új vezetői nagyban különböztek a régiektől; óvatosak voltak, és kerülték a felelősségvállalást. Valószínűnek tünik, hogy Koroljovot követően azért esett Vaszilij Misinre a választás, mert ő - elődjével ellentétben - közel állt az új elithez.

A felsorolt problémák ellenére, az 1970-es évek közepevége felé a Szovjetunió is küldhetett volna embert a Holdra. Ha úrrá lettek volna a nehézségeken, ha előtérbe került volna az erre vonatkozó politikai akarat, ha nem szükültek volna a gazdasági lehetőségek stb., talán megvalósulhatott volna az álom. De a tény ettől még tény marad. A szovjetek az N1 rakétát nem tudták korábban elkészíteni, mint az amerikaiak a Saturn-V-öst. Joggal tehetjük fel a kérdést: kellett-e a szovjeteknek ez a rakéta egyáltalán?

\section{NÉGYSZer ROBbant FEL az N1}

Misin már 1966-ban kiadta az intézkedést az N1 program felgyorsítására. Ez volt a negyedik, és egyben az utolsó kritikus pont. Számára mindent biztosítottak ahhoz, hogy a

Magyar Asztronautikai Társaság. ORCID: 0000-0001-7947-8645 
kialakult helyzetet megváltoztassa, és a dolgokat a „helyes" útra terelje, ő azonban ezt nem tette meg. Miért? Valószínű, hogy nem volt rá képes, és lehetséges, hogy nem is akarta. Talán azt hitte, hogy máris a helyes úton jár...

Természetesen elképzelhető, hogy Koroljov árnyékából kilépve be akarta bizonyítani, hogy ő sem rosszabb az elődjénél. Hiszen, ha sikerült volna a holdra szállás megvalósítása, akkor azonnal aranybetűkkel írták volna be a nevét a szovjet űrkutatás nagykönyvébe.

1966 novemberében Bajkonurban megkezdték az első N1 rakéta összeszerelését. Az indítását 1968 márciusára tervezték, de a valóságban erre csak majdnem egy évvel később került sor. Misin persze siettette a mérnököket, de a határidőt így sem sikerült tartani. A hasznos terhet igyekeztek még legalább öt tonnával megnövelni, akár a holdkomp tömegének csökkentése árán is. Ez természetesen azzal járt, hogy csak egyetlen embert tudnak a Holdra küldeni. A mérnökök mindent megtettek a feladat megoldása érdekében, hogy a Szovjetunió elsőként érje el a Holdat. Igyekezetük hiábavalónak bizonyult, mert a hajtóművek teljesítménye kicsi volt, és már a kezdetekkor kevés hasznos teherrel számoltak. A célt ily módon nem lehetett elérni.

Ebben az időszakban Misin ellenlábasai elhatárolódtak a tervektől, és várták, hogy a főtervező mikor „süllyed el”. Úgy tűnik, hogy szinte mindenki tudta, a 23,5 tonna hasznos teher még egy személy Holdra juttatásához is kevés lesz. Bár a kortársak visszaemlékezéseiben találunk erre

50. ábra. Kigördül az N1 a bajkonuri starthelyre (RKK Enyergija)

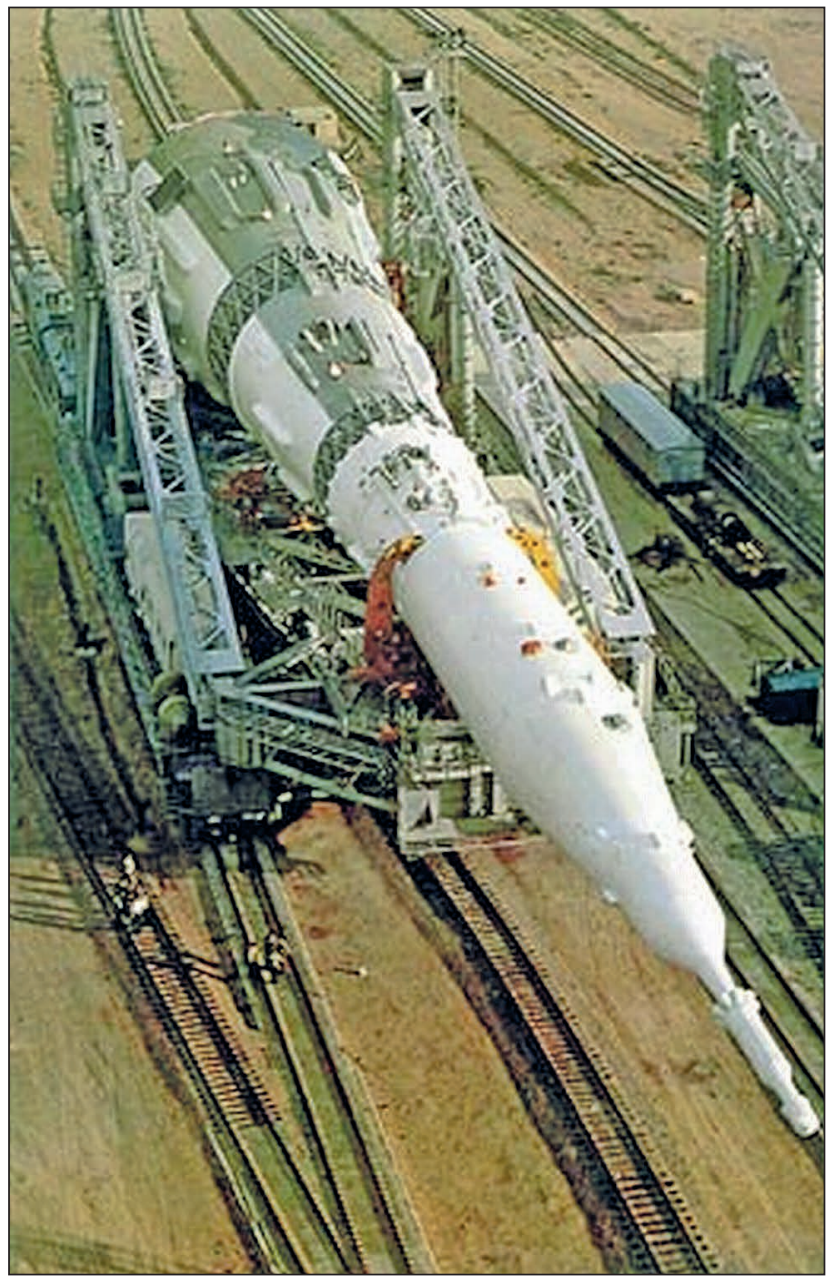

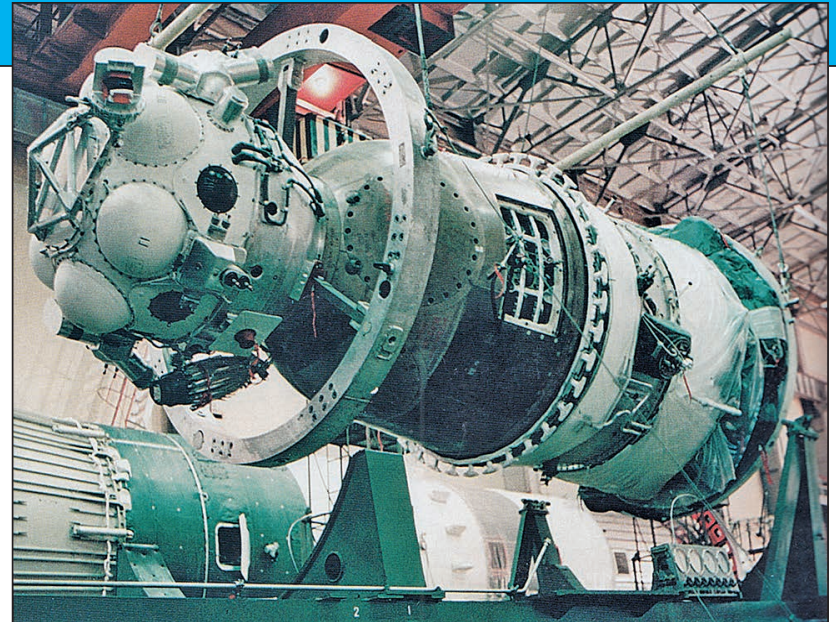

51. ábra. Mivel a Szojuz-LOK nem készült el időre, ezért a startoknál 7K-L1SZ (Zond) ürhajóval helyettesítették az L3-as szerelvényben (RKK Enyergija)

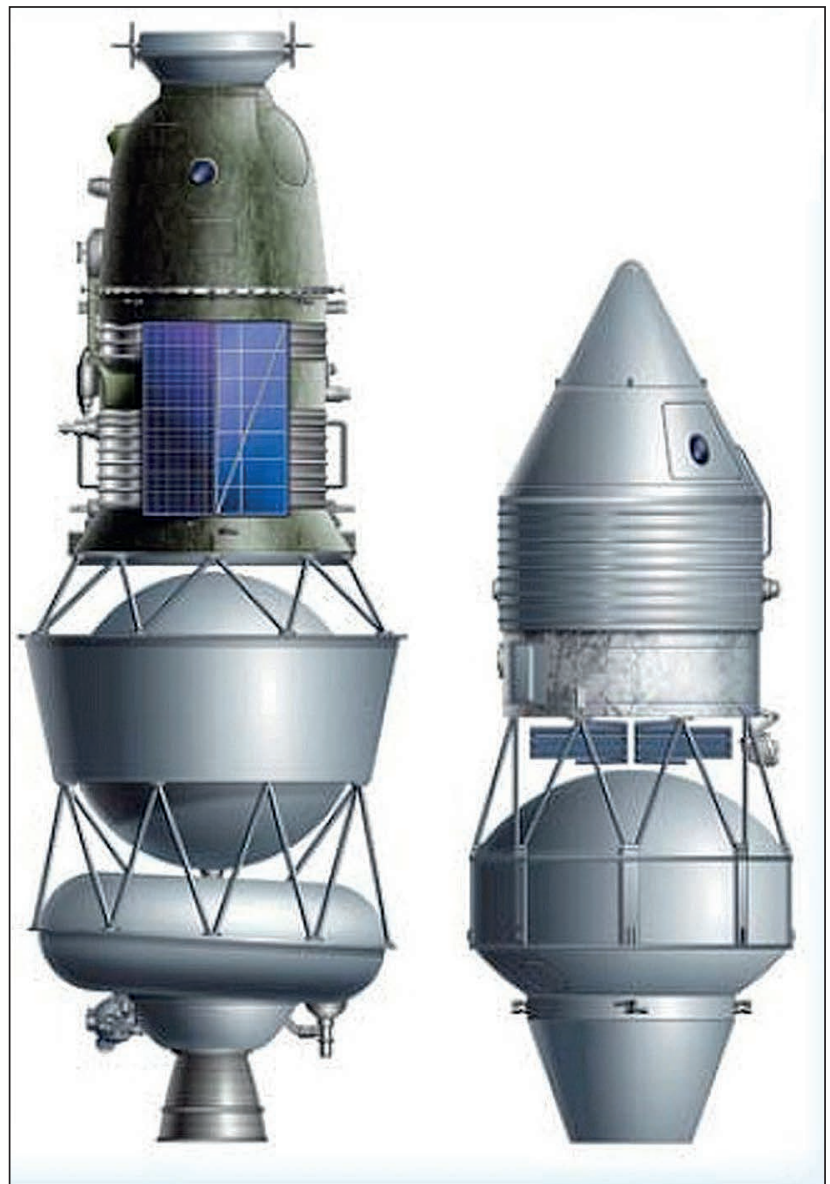

52. ábra. A 7K-L1 (orbitális kabin nélküli Szojuz) összehasonlítása Cselomej ürhajójával, amely meglepő hasonlóságot mutat az Apollóval (RKK Enyergija)

vonatkozó adatokat, de nyilvánvalóan senki sem akarta megégetni magát ebben a bonyolult helyzetben.

Amint már utaltunk rá, az N1 legnagyobb problémája - a kis teljesítményű hajtóművekből következően - az volt, hogy nem tudott elég nagy tömegű hasznos terhet Föld körüli pályára állítani ahhoz, hogy biztonságosan végrehajtható legyen a holdutazás. A második gond az volt, hogy még ezeket a hajtóműveket sem vetették alá teljes mélységű ellenőrzésnek földi próbapadon, és kísérleti repülésben sem próbálták ki azokat. Az NK-15-ös hajtóművek egyszeri indításúak voltak, és fennált a veszély, hogy közülük egy vagy esetleg több is meghibásodhat. Mai szemmel elké- 
pesztő a tervezők naivitása, illetve túlzott optimizmusa hiszen mindegyikük tapasztalt hajtómütervező és -építő volt. Tudniuk kellett tehát a meghibásodás nagyobb valószínüségéről, de valamiért mégis olyan döntést hoztak, hogy ez a probléma éppen olyan egyszerűen megoldható, mintha egy gépkocsi motorja mondaná fel a szolgálatot. Kitalálták, hogy az ilyen esetek kivédésére automatikus megoldást alkalmaznak. Ez volt a KORD (Hajtómű Működését Ellenőrző Rendszer), amely a tolóerő-szimmetria megmaradása érdekében, nemcsak a hibás, hanem a vele szemben lévő hajtóművet is kikapcsolja. Arra persze nem gondoltak, hogy a KORD is meghibásodhat. Nem vették számításba azt sem, hogy a hajtóművek, vagy az azokat kiszolgáló részegységek robbanás következtében is megsérülhetnek. Ilyen esetben pedig a KORD tehetetlen.

Az egyik N1 startja után az elektromos vezérlésben keletkezett hiba, aminek következtében a KORD nem egyet, hanem az összes hajtóművet leállította. A rakéta először eltért az iránytól, majd tolóerő hiányában visszazuhant a földre.

A hibát valószínűleg az elektromos pólusok felcserélése okozta. Ezek összekeverése, a szovjet űrkutatás során többször is előfordult, de az ilyen hibáért soha senkit sem vontak felelősségre. Minden rakétakomplexum belsejében rengeteg kábel van, és azok mindegyikében 20 -30 vezeték található. Az amerikaiaknál a vezetékeket nem lehetett összekeverni, mert teljes hosszukban színesek voltak, de a szovjeteknél - abban az időben - csak a vezetékek végét jelölték meg.

$\mathrm{Az}$ amerikaiak a rádióalkatrészeket is színnel jelölték meg, míg a szovjeteknél csak rányomták az ellenállásra, hogy például „1K2”, ami azt jelentette, hogy 1,2 k 2 . Ha egy alkatrész nehezen hozzáférhető helyen volt, semmilyen külső jel nem segített a felismerésében, könnyen el lehetett téveszteni, vagy felcserélni. Az amerikai alkatrészek bárhol helyezkedtek el, jól felismerhetőek voltak, könnyen és biztonságosan lehetett velük dolgozni. Egy színes rendszerben a gyakorlott ellenőr is könnyebben eligazodik, és hamar felismeri az elcserélt vezetékeket.

$\mathrm{Az}$ ilyen alacsony színvonalú technológiai kultúra nem azért maradt fenn, mert nem tudtak volna jobbat teremteni, hanem azért, mert számukra fontosabb volt a hagyományok őrzése, mint az elörehaladás. Mivel soha senki sem tervezett olyan rakétát, amelyen 30 hajtómű dolgozott volna, senki sem tudhatta, hogyan reagálnak majd a hatalmas tüzáradatban, amikor a rakéta felgyorsul, és milyen hatással lesz a hajtóművekre a rakétatestet körülölelő levegőáramlás. Sok volt tehát az ismeretlen tényező, amelyek bármelyike kedvezőtlenül befolyásolhatta a rakéta működését. Alapos ellenőrzések, kísérletek, próbák híján csak reménykedhettek a sikerben; de nem váltak be a hajtómüvek, nem vált be a KORD-rendszer, minden újítás fatális tévedésnek bizonyult.

1972-ben a szakértők megállapították, hogy ha az N1 rakéta fokozatait az NK-33-as hajtóművekkel látták volna el, akkor elérhették volna az áhított célt. Ez a megállapítás azonban már későn született meg. Ezt a négy indítás kudarca is „igazolta”, mint ahogy azt is, hogy a holdra szállás szovjet változata, vagyis az N1-L3 program alkalmatlannak bizonyult a végrehajtásra.

Az N1 első indítását 1969. február 20-ára tervezték, de a kedvezőtlen időjárás miatt egy nappal elhalasztották. Másnap, moszkvai idő szerint 12:17:55-kor startolt az N1-3L jelű rakéta, amelyen a Szojuz-LOK ürhajót és a holdkompot egy 7K-L1 (Zond) típusú automatikus ürhajóval helyettesítették. Az űrhajót az L3 rendszereivel és egy nagy teljesítményű fotóberendezéssel láttak el. A kísérlet sikere esetén az űrhajó megkerülte volna a Holdat, és jó minősé-

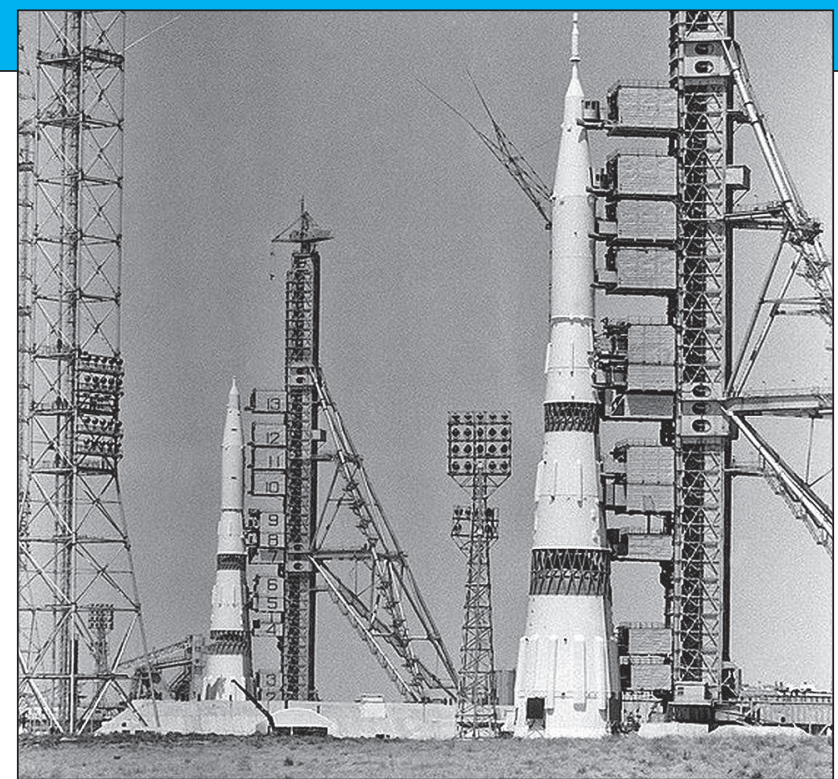

53. ábra. A bajkonuri két N1-es indítóállás, 1969 júniusában. Az előtérben az N1-5L, amely július 3-án startolt. A háttérben egy makett példány, amellyel a starthelyen szükséges méréseket végezték el. Jól látható, hogy a mentőrakéta helyén csak egy csonk van (GRIN)

gü felvételekkel tért volna vissza a Földre. A start utáni kb. hetedik másodpercben a 12-es és 24-es számú hajtómüvet a KORD-rendszer - tévesen! - kikapcsolta, de a rakéta tovább emelkedett. T+25 mp-kor az aerodinamikai nyomás keltette rezgések csökkentésére a hajtóművek tolóerejét lejjebb vették, majd T+66 mp-kor újra a maximálisra kapcsolták. Ekkor az erős vibráció következtében az egyik hajtómű oxigénvezetéke eltörött, és a folyékony oxigén kiömlött. A KORD azonnal lekapcsolta a hajtóművet, de a két szomszédos hajtómű - turbópumpáik túlmelegedése következtében - felrobbant. A 70. másodpercben, kb. 14 km-es magasságban a KORD már hiába álította le az összes hajtóművet, az N1 felrobbant, roncsai a starthelytől kb. 50 km-nyire a sztyeppére zuhantak. A baleset okait elemezve, a tervezők úgy döntöttek, hogy a rakétán freonos tűzoltó berendezést helyeznek el.

Az N1 (N1-5L) második próbájára a 7K-L1 automatikus űrhajóval és a holdkomp makettjével 1969. július 3-án, mindössze két héttel az Apollo-11 startja előtt került sor. Moszkvai idő szerint 23:18:32-kor gyújtották be a hajtómüveket. Amikor az emelkedő rakéta a villámhárító tornyok magasságába ért, az első fokozatban meghibásodott egy tüzelőanyag-szivattyú, majd a keletkezett tűzben a hajtómű felrobbant. A KORD-rendszer ezt észlelte, és leállította mind a 29, még működő hajtóművet. Az emelkedés hirte-

54. ábra. Az N1 második startja 13 nappal az Apollo-11 indítása előtt történt

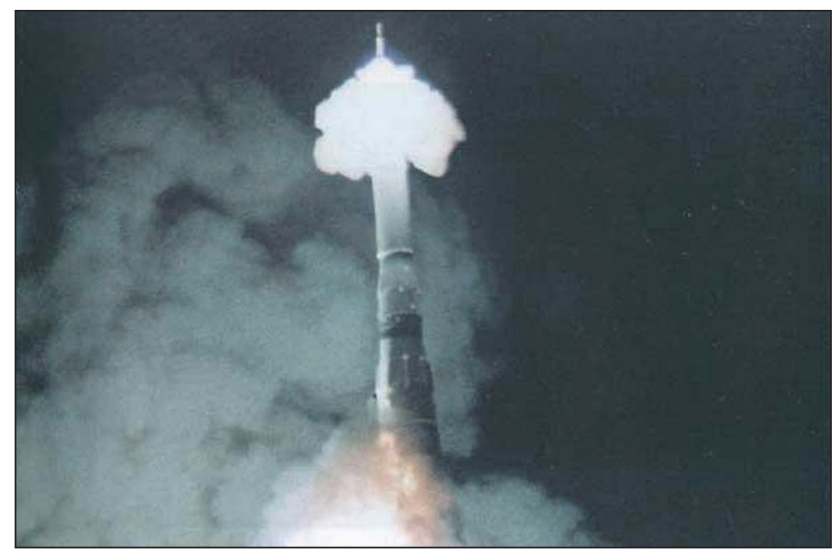


5. táblázat.

\begin{tabular}{|c|c|c|c|}
\hline Ürhajó (aktív) & Személyzet & Űrhajó (passzív) & Személyzet \\
\hline Szojuz-1 - 1967.ápr. & V. Komarov & Szojuz-2 - törölve & V. Bikovszkij \\
\hline & & & A. Jeliszejev \\
\hline & & & J. Hrunov \\
\hline Szojuz-3 - 1968. okt. & G. Beregovoj & Szojuz-2 - 1968. okt. & nincs \\
\hline Szojuz-4- 1969. jan. & V. Satalov & Szojuz-5 - 1969. jan. & B. Volinov \\
\hline & & & A. Jeliszejev \\
\hline & & & J. Hrunov \\
\hline Szojuz-8-1969. okt. & V. Satalov & Szojuz-7 - 1969. okt. & A. Filipcsenko \\
\hline & A. Jeliszejev & & V. Volkov \\
\hline & & & V. Gorbatko \\
\hline
\end{tabular}

6. táblázat.

\begin{tabular}{|c|c|c|c|c|c|}
\hline $\begin{array}{c}\text { Ürhajó } \\
\text { (aktív) }\end{array}$ & Személyzet & $\begin{array}{c}\text { Tartalék } \\
\text { személyzet }\end{array}$ & $\begin{array}{c}\text { Ürhajó } \\
\text { (passzív) }\end{array}$ & Személyzet & $\begin{array}{c}\text { Tartalék } \\
\text { személyzet }\end{array}$ \\
\hline Szojuz Kontakt-A & A. Filipcsenko & L. Vorobjov & Szojuz Kontakt-P & V. Lazarev & P. Klimuk \\
\hline & G. Grecsko & V. Jazdovszkij & & O. Makarov & J. Artyuhin \\
\hline
\end{tabular}

len lelassult, és 23 másodperccel a hajtóművek leállása után, a hordozórakéta visszazuhant az indítóállványra, miközben bekövetkezett a rakétatörténet legnagyobb robbanása. A mentőrendszer viszont sikeresen müködésbe lépett, és a $7 \mathrm{~K}-\mathrm{L} 1$ ürkabinja mindössze $2 \mathrm{~km}$-re a starthelytől, épségben földet ért.

A hatalmas robbanás a starthely mind az öt földalatti szintjét alaposan megrongálta. Az egyik villámhárító torony spirál alakba tekeredve dőlt el. A robbanás ereje a 145 méter magas kiszolgáló tornyot is leugrasztotta sínjeiről. A csodával határos módon - annak ellenére, hogy az indítórendszer jelentősen megsérült - emberi áldozata nem volt a balesetnek. A hatalmas kudarc most nem maradhatott titokban, mert az amerikai Nimbus-3 időjárás-figyelő műhold lefényképezte ezt a területet a robbanás előtt és után is. A felvételek kiértékelésekor megállapították, hogy a pusztítás milyen nagymértékű volt.

A Szovjetunió még egy kétségbeesett kísérletet tett. Az Apollo-11 expedíciójával egy időben indította az automatikus Luna-15-öt, hogy az amerikai űrhajósokat megelőzve, kőzetmintát hozzon a Holdról. A Luna-15 azonban a sima leszállás helyett a Holdba csapódott.

1971 júniusában újabb kudarc következett. Június 27-én moszkvai idő szerint 02:15:07 indult a harmadik N1 (N16L), ezúttal a második starthelyről. Ám ez sem hozott szerencsét. Nagyjából 250 méteres magasságban vezérmű hiba miatt a rakéta váratlan forgásba kezdett hossztengelye körül, majd a második és harmadik fokozat között kettétört. Pillanatokkal később az önállósodott felső részben lévő harmadik fokozat tüzelőanyag-tartálya felrobbant, majd a „B” és a „D” fokozat jutott hasonló sorsra. A levált alsó rész közben tovább repült, de a vezérmű már nem befolyásolta irányát. 51 másodperccel a start után lezuhant, és kb. 20 méter átmérőjű, 15 méter mély krátert hozott létre, szétrobbant darabjai $10 \mathrm{~km}^{2}$-nyi területen szóródtak szét. Máig megválaszolatlan kérdés, hogy a dátum szerint még a Föld körül keringő Szaljut-1 ürállomás személyzetével terveztek-e valamilyen közös kísérletet..

1972. november 23-án, moszkvai idő szerint 09:11:52kor ismét próbálkoztak. Úgy tűnt, hogy ezúttal elérik az annyira áhított sikert. Az N1-es rakéta (N1-7L) rendben felemelkedett, és a magasba tört. A repülés 107. másodpercében - mindössze 13 másodperccel az 1. fokozat, vagyis a rakéta legkritikusabb részének normális leállása előtt - a hossztengely irányában egyre erőteljesebb lökés- ingadozások jelentkeztek, valószínűleg egy vagy több hajtóműnél fellépő vibráció következtében. Az erősödő rezgések hatásaként a tartószerkezet eltört, és kb. 40 km-es magasságban a rakéta darabjaira esett szét.

Másféléves szünet után, az N1-L3M rakétával ismét starthoz készültek a szovjet szakemberek, és a tervezők remélték, hogy az 1974 augusztusára kitűzött újabb N1 indítás már sikeres lesz. 1974. május 15-én azonban felfüggesztették a további munkálatokat, és Vaszilij Misin helyére Valentyin Gluskót nevezték ki. Ez lett az N1 halálos ítélete. Augusztusban törölték a Misin által szorgalmazott ötödik, és az év végére tervezett hatodik startot, de Glusko még ezzel sem elégedett meg. Kiadta a parancsot a megmaradt példányok szétszerelésére. 1976 márciusában az N1 történetének végére pont került.

\section{ÜRHAJósOK a SZOVJet HoLd-PRogramban}

Az N1 problémáival szemben, az 1960-as évek közepétől az űrhajósok felkészítése zökkenőmentesen haladt. Erről Alekszej Leonov űrhajós vezérőrnagy az Aviacija $i$ koszmonavtyika (1990/7) című szaklapban számolt be: „A szovjet Hold-programot két fő részre tervezték. Az első a Hold megkerülése, a másik az ember holdra szállása volt. Az első szakasz az 1960-as évek közepén kezdődött, amikor a csillagvárosi Ürhajós Kiképző Központ is bekapcsolódott a program megvalósításába.

A második szakasz kissé problematikusabb volt. Habár még nem hagyták jóvá a programot, de Szergej Koroljov már beszélt nekünk a hatalmas hordozórakétáról, az N-1-ről, és a holdűrhajóról. Mi, űrhajósok akkor azt hittük, hogy a Holdprogram hosszú évekre meghatározza munkánkat. Már nemcsak a holdra szálásra gondoltunk, hanem más bolygók meghódításáról is álmodoztunk. Az élet azonban megmutatta, hogy álmodozásaink túlmentek a lehetőségeinken.

A Proton hordozórakéta, amelyet a Hold megkerülésére terveztek készen volt, és sikeresen bemutatkozott a gyakorlatban is. A Zond-sorozatból azonban csak minden második repülés volt sikeresnek mondható. 1968-ban világossá vált előttünk, hogy az amerikaiakat ebben a programban már nem tudjuk megelőzni. Pedig a Hold megkerülésére, majd a holdra szállásra 20 ember készült. Az első személyzetben én voltam a parancsnok és Oleg Makarov a fedélzeti mérnök. Együtt készültünk a Bikovszkij - 
